\title{
VNITŘNÍ STRUKTURA PRÁVA A KONCEPCE SYSTEMATIKY PRÁVA V DÍLECH H. L. A. HARTA A NIKLASE LUHMANNA
}

\author{
PAVEL ONDŘEJEK*
}

\begin{abstract}
An Internal Structure of Law and Conceptions of Systematicity of Law in the Works of H. L. A. Hart and Niklas Luhmann

In searching for answers to the question of what unifies current extensive and often disorganized legal system, we often turn to theoretical conceptions of a legal system. Transformations in post-war law characterized by the recognition of legal principles and values in law as abstract regulatory ideas fundamentally transform the prevailing paradigm of the legal system. Legal pluralism and the increasing regulation of social relations brought entirely new challenges. The relatively narrow topic of this article is a concept of the systematicity of law in the works of two important personalities of legal theory and sociology of law of the last century, H. L. A. Hart and Niklas Luhmann, and their influence on current conception of a legal system.
\end{abstract}

Klíčová slova: jednota a diferenciace práva; systém práva; H. L. A. Hart; Niklas Luhmann; vnitřní struktura práva

Keywords: unity and differentiation of law; legal system; H. L. A. Hart; Niklas Luhmann; internal structure of law

DOI: $10.14712 / 23366478.2019 .33$

\section{ÚVOD $^{1}$}

Při hledání odpovědi na otázku, co současný složitý a mnohdy nepřehledný právní systém sjednocuje, se často obracíme k teoretickým koncepcím práva jako systému. $\mathrm{V}$ odborných pracích řady autorů nalézáme různé argumenty vztahující se k tomu, co činí z právního řádu jednotný a koherentní systém. Účelem tohoto článku nebude poskytnout přehled jednotlivých teorií ani historický vývoj systematiky práva, nýbrž zaměřit se na dvě významná pojetí a porovnat je rovněž z hlediska současných diskusí o systematice práva. Cílem tak bude primárně posouzení, nakolik jsou myšlenky H. L. A. Harta a Niklase Luhmanna př́nosné v současné době, kdy v posledních několika desetiletích dochází k významným proměnám ve struktuře právních řádů, které

* JUDr. Pavel Ondřejek, Ph.D., Katedra teorie práva a právních učení, Právnická fakulta Univerzity Karlovy.

1 Tento článek je publikován v rámci řešení projektu GA ČR reg. č. 19-10723S s názvem „Co současné právo sjednocuje a co jej fragmentarizuje z pohledu právní teorie a soudní praxe?“. 
se zároveň stávají stále složitější, více mezi sebou provázané, ale také regulující stále rozšiřující se počet společenských vztahů. ${ }^{2}$

Podle mého názoru prochází proměnami všechny konstitutivní rysy práva jako systému: mění se prvky, z nichž je právo tvořeno (v právní teorii již nejde výlučně o právní normy, nýbrž minimálně od druhé poloviny dvacátého století jsou uznávány jako prvky práva rovněž právní principy a významnou roli hrají i hodnoty v právu a - jak se pokusím argumentovat dále - také některé doktrinární teorie). S tímto rozšiřováním druhů pravidel a prvků práva se mění i jeho struktura. $\mathrm{V}$ této souvislosti blíže nastíním koncepci vnitřní struktury práva, $v$ níž navazuji především na autory z německého prostředí, ${ }^{3}$ ovšem v řadě ohledů reflektovaných současnou českou právní vědou. ${ }^{4}$

Jedním z cílů tohoto článku bude obhájit tezi, že i na právní rád můžeme aplikovat obecná kritéria pojmu systém, který je používán v celé řadě vědních oborů..$^{5}$ Ostatně aplikace obecné systémové teorie je spojena rovněž s jedním proudem právně-teoretického myšlení, který je označován jako systémová teorie práva. Ta bývá nejčastěji spojována s německým sociologem a právníkem Niklasem Luhmannem, ${ }^{6}$ který zanechal rozsáhlé dílo, v němž se zdaleka nezabýval jen právním systémem. Zároveň je však třeba dodat, že Luhmannova teorie autopoietického systému práva se nikdy nestala hlavním směrem právního myšlení.

Rovněž H. L. A. Hart se pokusil ve svém díle přinést ucelený pohled na právo jako systém. Východiska výše uvedených autorů i jejich koncepce se však v řadě bodů zá-

2 Volba výše uvedených autorů odpovídá především podobnému období, kdy se tyto teorie systematiky práva rozvíjejí. $Z$ toho důvodu se nebudu na tomto místě věnovat některým starším, přesto významným teoriím systému práva, napríklad Kelsenově, resp. Merklově teorii stupňovité výstavby právního rádu.

3 ESSER, J. Grundsatz und Norm in der Richterlichen Fortbildung des Privatrechts. 2. Aufl. Tübingen: Mohr Siebeck, 1964, CANARIS, C.-W. Systemdenken und Systembegriff in der Jurisprudenz entwickelt am Beispiel des deutschen Privatrechts. In: NEUER, J. - GRIGOLEIT, H. C. (eds.). Claus-Wilhelm Canaris. Gesammelte Schriften. Bd. 1. Rechtstheorie. Berlin, Boston: Walter de Gruyter, 2012, s. 191-346. $\mathrm{Z}$ novějších prací orientovaných zejména na veřejné právo viz např. ISENSEE, J. Gemeinwohl im Verfassungsstaat. In: ISENSEE, J. - KIRCHHOF, P. (eds.). Handbuch des Staatsrechts der Bundesrepublik Deutschland. 3. Aufl. Heidelberg: C. F. Müller, 2006, s. 34 a násl. JESTAEDT, M. Die Verfassung hinter der Verfassung: Eine Standortbestimmung der Verfassungstheorie. Paderborn, München, Wien, Zürich: Ferdinand Schöningh, 2009.

$4 \mathrm{~K}$ proměnám struktury práva $\mathrm{v}$ druhé polovině dvacátého století viz zejm. HOLLÄNDER, P. Filosofie práva. 2. vyd. Plzeň: Aleš Čeněk, 2012, s. 19 a násl. K tématu právních principů viz též BOGUSZAK, J. (ed.). Právní principy. Pelhřimov: Vydavatelství 999, 1999. KÜHN, Z. Aplikace práva ve složitých př́ipadech. K úloze právnich principu v judikatuře. Praha: Karolinum, 2002. WINTR, J. Řiše principü. Obecné a odvětvové principy českého práva. Praha: Karolinum, 2006. TRYZNA, J. Právní principy a právní argumentace. K vlivu právních principů na právní argumentaci při aplikaci práva. Praha: Auditorium, 2010.

5 Pojem systému je v řadě současných oborů spojován se vznikem obecné systémové teorie (General Systems Theory), jejímž zakladatelem byl rakouský biolog Ludwig von Bertalanffy (VON BERTALANFFY, L. General Systems Theory. Foundations, Development, Applications. New York: George Braziller, 1969). Ta pronikla do celé řady vědních oborů (kromě práva se se systémovými př́stupy setkáváme například v chemii, biologii, kybernetice, sociologii, psychologii a dalších disciplínách). Důvodem je patrně podobnost některých problémů, vyskytujících se napříč různými disciplínami, jejichž řešení nabízí právě obecná systémová teorie - viz WILLKE, H. Systemtheorie I. - Grundlagen. 7. Aufl. Stuttgart: Lucius \& Lucius, 2005, s. 3.

6 K systémové teorii podrobněji viz CALLIES, G. P. Systemtheorie. In: BUCKEL, S. - CHRISTENSEN, R. - FISCHER-LESCANO, A. Neue Theorien des Rechts. Stuttgart: Lucius \& Lucius, 2006, s. 199-221, BÜLLENBACH, A. Systemtheorie im Recht. In: KAUFMANN, A. - HASSEMER, W. - NEUMANN, U. (eds.). Einführung in Rechtsphilosophie und Rechtstheorie der Gegenwart. 7. Aufl. Heidelberg: C. F. Müller, 2004, s. 428-457. 
sadně liší, a proto podle mého názoru zaslouží podrobnějšího srovnání. Přestože oba vytvořili zásadní díla od 60. do 90. let minulého století, domnívám se, že jejich závěry jsou použitelné i pro popis současné systematiky práva, které prochází v tomto ohledu určitými proměnami.

Výše zmíněnému problému se věnuje např́iklad Pavel Holländer, který při charakteristice dynamické normotvorby v současném státě popisuje obsahový a strukturální komponent dekonstrukce práva. Obsahová složka je dána zejména ztrátou schopnosti formulovat a interpretovat účely práva, strukturální pak relativizací tradičních pořádacích principů práva (což se projevuje například v přijímání komplexních úprav, které odmítají subsidiární působení obecných právních předpisů v soukromém anebo veřejném právu). ${ }^{7}$ Souhlasím s názorem, že v právu pưsobí celá řada tendencí posilujících jeho fragmentaci, na druhou stranu o to důležitější je podle mého názoru potřeba provádět rekonstrukci systematiky práva. Základním cílem tohoto článku však nebude pouze obhajoba teze o existenci vnitřní struktury práva, nýbrž propojení této idey s myšlenkami H. L. A. Harta a Niklase Luhmanna o systematice práva, a tedy hledání průniků teorií, které se na první pohled zdají být poměrně vzdálené. ${ }^{8}$

\section{NIKLAS LUHMANN A AUTOPOIETICKÝ SYSTÉM PRÁVA}

Německý sociolog a právník Niklas Luhmann (1927-1998) je v teorii a sociologii práva znám zejména svým popisem práva jakožto autopoietického systému. Podle Jiř́ho Přibáně, který v řadě myšlenek na jeho dílo již koncem devadesátých let navázal a zpř́ístupnil jej tak české právní vědě, ${ }^{9}$ tato teorie ,V sociálních a právních vědách představuje nový způsob, jak formulovat a tematizovat nejpůvodnější otázky systémového chování práva a konstitutivní problémy těchto věd“. ${ }^{10}$

Luhmann usiluje o popis komplexnějších jevů, než je právo. Buduje ,sociální teorii sociálních teorií“, která se neváže ke konkrétním historickým ani kulturním

7 HOLLÄNDER, P. Soumrak moderního státu. In: AGHA, P. (ed.) a kol. Budoucnost státu? Praha: Academia, 2017, s. 64.

8 Účelem článku bude rovněž poskytnout argumenty proti koncepcím tvrdícím, že současné právo žádný systém netvoří, např́klad proto, že v něm jde primárně o prosazování moci či zájmů jednotlivců (SAMPFORD, C. The Disorder of Law: A Critique of Legal Theory. Oxford: Basil Blackwell, 1989. Viz též NOBLES, R. - SCHIFF, D. Observing Law through Systems Theory. Oxford, Portland: Hart Publishing, 2013, s. 3-5), př́ípadně proto, že autoři zastávají postmoderní skepsi k velkým teoriím systematiky práva (v české literatuře toto téma velmi podrobně zpracovává Martin Škop, jehož práce se vyhýbají povrchní kritice současného práva z pozic postmodernismu - viz zejm. ŠKOP, M. Právo v postmoderní situaci. Brno: Masarykova univerzita, 2008, s. 25 a nás1.)

9 PŘIBÁŇ, J. Sociologie práva. Praha: Sociologické nakladatelství, 1996, zejm. 10. kapitola: Právní systém moderní společnosti a jeho legitimita, s. 129-145. Již na tomto místě je však třeba zmínit, že práce J. Přibáně se od Luhmannovy teorie významně odchylují, na což upozorňuje v české literatuře Jan Kysela (viz KYSELA, J. Právo jako relativně uzavřený systém a dvojí pojetí výjimečného stavu. Předběžné ohledání schmittovského tématu. In: BÍLKOVÁ, V. - KYSELA, J. - ŠTURMA, P. (eds.). Výjimečné stavy a lidská práva. Praha: Auditorium, 2016, s. 20-21).

10 PŘIBÁŇ, Sociologie práva, s. 135. 
souvislostem. ${ }^{11}$ Prostřednictvím univerzální teorie sociálních systémů založené na systémovém paradigmatu popisuje kromě práva fungování politiky, ekonomiky, vědy, umění a dalších fenoménů, které označuje společenské subsystémy (resp. dílčí systémy, Teilsysteme). ${ }^{12}$

Klíčovou pro porozumění Luhmannovy teorie je otázka funkcionální diferenciace (Aufdifferenzierung) společnosti. Ta představuje hlavní rozdíl mezi Parsonsovou teorií společnosti založenou naopak na integraci a uchování struktur. ${ }^{13}$ Na rozdíl od Talcotta Parsonse se Luhmann domnívá, že systém nevzniká na základě společně sdílených hodnot a norem, nýbrž „ze série návazných, v zásadě nahodilých selekcí uvnitř systémů, které se vzájemně vymezují a determinují“. 14

Základní charakteristikou společenských subsystémů, včetně práva, je jejich autopoietický charakter. Luhmann poprvé aplikuje tento pojem (původem z biologie) na sociální systémy na počátku 80 . let, ${ }^{15}$ přičemž popis práva jako autopoietického systému představuje hlavní Luhmannovu inovaci v systémovém př́stupu ke společnosti a právu. ${ }^{16} \mathrm{~V}$ Luhmannově pojetí jsou všechny společenské subsystémy autopoietické, nebot' autonomně popisují společenskou realitu. Luhmann hovoří v této souvislosti o kódování - pojem si v druhé polovině minulého století vypůjčil z tehdy vznikající kybernetické vědy. Právníci hodnotí faktické okolnosti tak, že je označují jako souladné s právem anebo protiprávní - uplatňují tak binární kód právní/protiprávní. Podle Luhmanna je pojem kódu přesnější než benthamovský příkaz, nebot' se tím můžeme vyhnout obtížné otázce zdroje platnosti práva. ${ }^{17}$ Právě úsilí o odmítání otázek po vnějších zdrojích platnosti práva je charakteristické pro teorii autopoietických systémů, čímž se tato teorie liší nejen od nonpozitivistických směrů, ale i od většiny pozitivistických př́stupů, které odvozují platnost práva $\mathrm{v}$ konečném důsledku z faktických okolností. ${ }^{18}$

11 KING, M. - THORNHILL, C. Niklas Luhmann's Theory of Politics and Law. Palgrave: Macmillan, 2003, s. 1.

$12 \mathrm{~V}$ tomto ohledu je třeba vnímat celé Luhmannovo dílo věnované popisu sociálního systému. Jedná se o komplex rámovaný prací Sociální systémy, která poprvé vyšla jako LUHMANN, N. Soziale Systeme: Grundriß der allgemeiner Theorie. Frankfurt am Main: Suhrkamp, 1984 (v českém překladu: LUHMANN, N. Sociální systémy: Nárys obecné teorie. Praha: CDK, 2006), na kterou navazují studie dílčích společenských subsystémů. V tomto článku se budu věnovat především jeho práci Das Recht der Gesellschaft. Frankfurt am Main: Suhrkamp Verlag, 1993 (anglický překlad: LUHMANN, N. Law as a Social System. Oxford: Oxford University Press, 2004), v němž jsou aplikovány obecné doktríny Luhmannovy teorie společenského systému na právo. Luhmannova teorie je shrnuta $\mathrm{v}$ jeho poslední práci LUHMANN, N. Theory of Society. Sv. 1 a 2. Stanford: Stanford University Press, 2012 (orig. Die Gesellschaft der Gesellschaft. Frankfurt am Main: Suhrkamp, 1997).

13 ŠUBRT, J. - BALON, J. Soudobá sociologická teorie. Praha: Grada Publishing a. s., 2010, s. 155.

14 ŠUBRT, J. Niklas Luhmann: Komplexita, evoluce, kontingence. In: ŠUBRT, J. a kol. Soudobá sociologie I. (Teoretické koncepce a jejich autoři). Praha: Karolinum, 2007, s. 105.

15 KLYMENKO, I. Autopoiesis. In: JAHRAUS, O. - NASSEHI, A. (eds.). Luhmann Handbuch. LebenWerk - Wirkung. Stuttgart: J. B. Metzler, 2012, s. 69.

16 RITZEN, G. Modern Sociological Theory. 5th ed. New York: McGraw Hill, 2000, s. 186.

17 LUHMANN, Law as a Social System, s. 173.

18 Např́ílad Kelsenova základní norma - Grundnorm - je produktem revoluce znamenající diskontinuitu s předchozím právem - viz KELSEN, H. General Theory of Law and State. Cambridge, Massachusetts: Harvard University Press, 1949, s. 117. Jak popíšu níže, rovněž Hartovo pravidlo uznání jakožto standard platnosti všech dalších právních pravidel v určitém právním řádu není odvozeno z ničeho jiného než ze společenského faktu uznání soudy a jinými orgány aplikujícími právo (viz též POSTEMA, G. A Treaties of Legal Philosophy and General Jurisprudence. Vol. 11. Legal Philosophy in the Twentieth Century: The Common Law World. Dordrecht: Springer, 2011, s. 270). 
Namísto legitimizačních zdrojů se tak právo v Luhmannově pojetí obrací pouze $\mathrm{k}$ sobě samotnému, což je však problematické, protože právo nefunguje mimo sociální realitu. Tato cirkularita práva přesto představuje podle Eduarda Báránye ,jedno z nejsilnějších vysvětlení relativního se uzavírání práva a jeho postavení v postmoderním světě uzavírajících se, ale proměnlivých sociálních systémü“. 19

Uvažování v duálním kódu právní/protiprávní není cizí ani v české právní teorii, nebot' stejným způsobem tradičně klasifikujeme právní skutečnosti anebo hodnotíme chování člověka. ${ }^{20}$ Jednotlivé společenské systémy však nemohou fungovat pouze na základě existence kódu, který se uplatňuje na společenskou realitu, kromě nich musí existovat způsob, jakým hodnotu kódu (v právu kritérium právní/protiprávní) konkrétní skutečnosti priřradíme. Tyto postupy nazývá Luhmann programy, ${ }^{21} \mathrm{v}$ souladu s autopoietickým charakterem práva však programování v právu nevzniká jako výsledek činnosti vnějších aktérů, nýbrž jako výraz autonomní strukturace práva. ${ }^{22} \mathrm{~V}$ ryzí podobě se tak projevuje jedna z nejproblematičtějších tezí Luhmannovy teorie, podle níž lidé netvoří součást společenských systémů, nýbrž jejich okolí. ${ }^{23}$ Tato myšlenka úzce souvisí s tezí o komunikaci jakožto základu každého společenského subsystému. Komunikace $\mathrm{v}$ právu, ale i jiných dílčích subsystémech se děje převážně prostřednictvím jazyka. ${ }^{24}$ Komunikaci je potřeba odlišit od vnitřních představ a myšlenek jednotlivců, které nejsou sdělovány a které tvoří tzv. psychický systém, odlišný od sociálního systému. ${ }^{25}$

Zároveň však platí, že komunikace prostřednictvím jazyka se děje i v jiných subsystémech. Co tedy představuje specifičnost jednotlivých způsobů komunikace v sociálních subsystémech? Podle Niklase Luhmanna to jsou právě specifické kódy a programy, které se v nich vyskytují. V právu pak luhmannovské programy představují právní normy a jiná pravidla, protože na základě nich přiřadíme konkrétnímu jednání aktéra nebo události nezávislé na vůli aktéra atribut (kód) právní nebo protiprávní. ${ }^{26}$

Klíčový pojem Luhmannovy teorie - autopoiesis - se projevuje rovněž ve vlastnosti právního a jiných společenských subsystémů označované jako operační uzavřenost. Ta znamená, že každý společenský subsystém si nárokuje vlastní popis reality v důsledku specifického kódu (v právu legalita/ilegalita) i programů (pravidel sloužících k přiřazování tohoto kódu jednotlivým skutečnostem). Výsledkem toho je stav, kdy právo, ekonomie, politika, věda, prŕípadně média mohou sledovat jeden určitý problém (např́íklad adopce dětí páry stejného pohlaví) a izolovat z tohoto problému jen ty skutečnosti, které hodnotí vlastními kritérii (např́íklad: je legální nebo ilegální, vede z ekonomického hle-

19 BÁRÁNY, E. Cirkularita v práve. Právny obzor, 2012, roč. 95, č. 2, s. 123.

20 V některých př́ípadech si všímáme složitějších možností chování praeter legem anebo in fraudem legis viz např. GERLOCH, A. Teorie práva. 7. vyd. Plzeň: Aleš Čeněk, 2017, s. 153-154. I v těchto př́ípadech však nakonec umíme chování posoudit jako souladné s právem anebo protiprávní - v soukromém právu platí zásada legální licence, ve veřejném právu mohou orgány jednat pouze secundum et intra legem.

21 LUHMANN, Law as a Social System, s. 192.

22 Tamtéž, s. 176.

23 Přesněji řečeno, lidé jsou psychickými systémy, které stojí vně sociálních systémů, mezi nimiž však dochází k strukturálním vazbám (structural coupling) - KING, THORNHILL, c. d., s. 32.

24 Spíše výjimečně se objevuje komunikace pomocí symbolů či jiných prostředků.

25 NOBLES, SCHIFF, Observing Law through Systems Theory, s. 28-29.

26 NOBLES, R. - SCHIFF, D. Introduction. In: LUHMANN, N. Law as a Social System. Oxford: Oxford University Press, 2004, s. 17. Srov. rovněž vymezení v BÁRÁNY, E. Pojmy dobrého práva. Žilina: Poradca Podnikatel'a, 2007, s. 26. 
diska k efektivnímu nebo neefektivnímu uspořádání, má být schválena nebo odmítnuta). Význam takového př́stupu spočívá podle Jiřího Přibáně v tom, že představuje „,nový způsob, jak popsat a porozumět systému pozitivního práva v nejobecnějších sociálních souvislostech moderní západní společnosti“. ${ }^{27}$ Výhodou je právě ona izolace jevů důležitých pro právo, protože stále složitější společenské uspořádání vytvárí tlak na směšování kritérií (například ekonomická analýza práva usiluje o zdůraznění kritérií efektivity v právu).

\section{H. L. A. HART A SYSTÉM PRÁVA JAKO JEDNOTA PRIMÁRNÍCH A SEKUNDÁRNÍCH PRAVIDEL}

Oxfordský profesor H. L. A. Hart (1907-1992) ve své nejznámější knize Pojem práva ${ }^{28}$ rozvíjí myšlenky poprvé představené na Holmesově přednášce s názvem Pozitivismus a oddělení práva a morálky, ${ }^{29}$ která měla být obhajobou právně pozitivistického a analytického přístupu k právu, z něhož (byt' v podobě označované jako inkluzivní nebo soft-pozitivismus) H. L. A. Hart vycházel v celém svém díle. ${ }^{30}$

Hartovo dílo lze charakterizovat jako nové pojetí analytické jurisprudence, významně se lišící například od teorie normativismu, ale také od anglosaského směru právního pozitivismu 19. století, reprezentovaného např́klad Johnem Austinem. Zatímco představitelé normativismu přejímali konceptuální př́stup k právu, tedy interpretovali právo prostřednictvím analýzy klíčových pojmů, Roger Cotterrell naproti tomu označuje Hartův př́stup ,lingvistickým empiricismem“. ${ }^{31}$ Chápe jej tak, že pojmy nejsou pro Harta představiteli reálně existujících objektů, nýbrž samy realitu konstituují. ${ }^{32} \mathrm{Ne}$ jsou to tedy abstraktní analýzy pojmů, nýbrž jejich užívání příslušníky určitého státu, zejména pak soudci a úředníky (pro něž používá označení veřejní činitelé - officials), tj. osobami, které právo aplikují, interpretují a dotvářejí. ${ }^{33} \mathrm{~V}$ tom spočívá Hartova podoba teze o sociálním faktu, tedy komplexní, institucionalizované sociální praxi, jakožto zdroji normativity práva. Naproti tomu, pro Jeremyho Benthama a Johna Austina je tímto sociálním faktem existence suveréna, který vydává příkazy, jež jsou příslušníky společnosti obecně respektovány. ${ }^{34}$

Dále je třeba zdůraznit, že Hartův př́istup není přes tvrzenou tezi o právu jako sociálním faktu čistě deskriptivním sociologickým popisem fungování práva (který nazývá

27 Pर̌IBÁŇ, J. Systémová teorie a sociologie práva. Právník, 1994, roč. 133, č. 11, s. 919.

28 HART, H. L. A. The Concept of Law. 2nd ed. Oxford: Clarendon Press, 1994, český překlad HART, H. L. A. Pojem práva. Praha: Prostor, 2010.

29 HART, H. L. A. Positivism and the Separation of Law and Morals. Harvard Law Review, 1958, roč. 71, č. 4, s. 593-629. K okolnostem vzniku přednášky viz LACEY, N. A Life of H. L. A. Hart. The Nightmare and the Noble Dream. Oxford: Oxford University Press, 2004, s. 196 a násl.

30 HIMMA, K. E. Inclusive Legal Positivism. In: COLEMAN, J. - SHAPIRO, S. (eds.). The Oxford Handbook of Jurisprudence and Philosophy of Law. Oxford: Oxford University Press, 2002, s. 125.

31 COTTERRELL, R. The Politics of Jurisprudence. A Critical Introduction to Legal Theory. 2nd ed. Oxford: Oxford University Press, 2003, s. 83 a násl.

32 Tamtéž, s. 87.

33 HART, Pojem práva, s. 122.

34 HIMMA, c. d., s. 126. 
externím pohledem: external point of view). Naopak, speciální charakter právních pravidel je třeba chápat z hlediska perspektivy účastníka systému (internal point of view), internalizujícího si daná pravidla, který je schopen zároveň jejich kritické reflexe. ${ }^{35}$ $\mathrm{Z}$ toho důvodu nejsou právní pravidla chápána sociologicky jako predikce určitého chování, nýbrž normativně jako pravidla, s nimiž účastnící systému pojí výrazy jako např̀. „mít povinnost“" (should, ought to). ${ }^{36}$

Vzhledem k tomu, že každá forma složitější společenské regulace vyžaduje aplikaci obecných pravidel, tj. pravidel vztahujících k určité trrídě osob a třídě věcí, právních vztahů či práv a povinností, nikoliv jednotlivých př́kazů adresovaných každému jednotlivci, efektivita práva pak závisí na schopnosti rozeznat a určit individuální prrípady, na něž obecná pravidla, standardy a principy dopadají. ${ }^{37}$ Soudci jsou na straně jedné vázáni předem stanovenými pravidly, avšak v určitých situacích mohou svým rozhodnutím právo vytvořit. V této otázce se Hart shoduje naprríklad s Kelsenem, který však proti této roli soudů silně brojí, když apeluje na ústavní soudy, aby svá rozhodnutí neopíraly o vágní pojmy, jako je spravedlnost, rovnost, svoboda. ${ }^{38}$ Hartovo pojetí však diskreci soudců v obtížných př́padech neomezuje. I proto lze hodnotit význam soudů pro identifikaci pravidel právního systému jako rovnocenný významu zákonodárce, podle některých autorů dokonce ještě významnějšíi. ${ }^{39}$

Gerald Postema vystihuje podstatu Hartova pojmu práva jako institucionalizovaného systému pravidel. ${ }^{40}$ Toto vymezení je třeba upřesnit, aby vynikly rozdíly mezi Hartem a dalšími představiteli právního pozitivismu, neoinstitucionalismu a jiných směrů právního myšlení. Výše jsem poukázal na rozdíl, kdy namísto analýzy a postulování abstraktních norem (což je např́klad Kelsenův př́istup) se Hart věnuje fungování pravidel ve společnosti a roli institucí, zejména soudů aplikujících právo.

Pokud Hart uvažoval o právu jako o systému, je třeba rovněž zmínit, že v knize Pojem práva přesto neusiluje o přesnou definici práva, z čehož logicky plyne, že se nevěnuje ani exaktní definici systému práva. Samotná otázka systému a systematiky práva proto $\mathrm{v}$ jeho díle není zpracována komplexně, a je ji tedy třeba popsat s ohledem na jím popsané vlastnosti práva a pravidel, jež se v něm vyskytují.

35 COTTERRELL, c. d., s. 96. WATKINS-BIENZ, R. M. Die Hart-Dworkin Debatte. Ein Beitrag zu den internationalen Kontroversen der Gegenwart. Berlin: Duncker \& Humblot, 2004, s. 36-38. COLOTKA, P. - KÁČER, M. - BERDISOVÁ, L. Právna filozofia dvadsiateho storočia. Praha: Leges, 2016, s. 36-37. Pro původní Hartův popis viz: HART, Pojem práva, s. 13, 97 a násl.

36 HART, Pojem práva, s. 88-89.

37 Tamtéž, s. 129.

38 KELSEN, H. Wer soll der Hüter der Verfassung sein? In: KLECATSKY, H. - MARCIC, R. - SCHAMBECK, H. (eds.). Die Wiener rechttheoretische Schule. Schriften von Hans Kelsen, Adolf Merkl, Alfred Verdross. II. Band, Wien: Verlag Österreich, 2010, s. 1549-1550 a komentář k této pasáži v VINX, L. Hans Kelsen's Pure Theory of Law. Legality and Legitimacy. Oxford: Oxford University Press, 2007, s. 164.

39 POSTEMA, c. d., s. 319-320. Brian Bix uvádí, že hlavním smyslem Hartovy konstrukce otevřené textury a diskrece při rozhodování soudů, je postavit se dvěma významným směrům právního myšlení: na straně jedné právnímu realismu, který zjednodušeně přichází s tezí, že výsledek soudního rozhodování je relativně málo ovlivněn právními normami, na straně druhé přirozenoprávní naukou, podle níž složité případy aplikace práva dokazují, že neexistuje striktní oddělení práva a morálky. Obě tyto koncepce jsou neslučitelné s Hartovým pozitivistickým zkoumáním práva. Viz BIX, B. Jurisprudence. Theory and Context. 6th ed. London: Sweet \& Maxwell, 2012, s. 47.

40 POSTEMA, c. d., s. 268. 
S úvahami o prvcích právního systému úzce souvisí Hartova kategorizace druhů pravidel v právu. Podle něj můžeme rozlišovat jednak pravidla opravňující $\mathrm{k}$ výkonu pravomocí (power-conferring rules) a dále pravidla ukládají povinnosti (duty imposing rules). ${ }^{41}$ Kromě těchto druhů uvažuje Hart o dvou úrovních pravidel: pravidla primární (vlastní pravidla chování určena adresátům práva) a sekundární (meta-pravidla, tedy pravidla o pravidlech, určená veřejným činitelům, kteří mají povinnost udržovat systém pravidel). ${ }^{42}$ Hart ke koncepci sekundárních pravidel dochází analýzou nedostatků, které by vykazovala společnost, kdyby v ní existovala regulace pouze formou primárních pravidel, tedy povinností určených adresátům práva. Tyto jednotlivé povinnosti by existovaly jako samostatná pravidla netvořící systém, protože by jim chyběly jakékoliv společné znaky. ${ }^{43}$ Ve společnosti by obtížně existovala kontrola dodržování pravidel, nebyla by zajištěna dynamika práva a nebylo by ani možné říci, jak řešit situaci sporu o právo. ${ }^{44}$ To vede Harta ke kategorizaci trrí skupin právních pravidel tvořících sekundární pravidla, která napravují výše uvedené nedostatky „primitivního“ právního systému, založeného výlučně na primárních pravidlech. Tato sekundární pravidla jsou, jak známo: pravidla změny (rule of change) - umožňující zavádět nová pravidla ve společnosti a překonávající tak statický charakter právního systému, ${ }^{45}$ pravidla soudního rozhodování (rule of adjudication) - překonávající neúčinnost společenského působení tím, že obsahují zmocnění $\mathrm{k}$ autoritativnímu rozhodování sporů o právo, ${ }^{46}$ a pravidla identifikace, uznání (rule of identification/rule of recognition), které je pro právní systém klíčové, a proto se o něm zmíním podrobněji.

Pokud jsem výše konstatoval, že pro právo je v Hartově pojetí charakteristická za prvé normativní stránka - jde o systém pravidel, a za druhé praxe úředníků, kteří s tímto pravidlem jako s právem zacházejí, obě charakteristiky se sbíhají u klíčového pojmu pravidlo uznání (rule of recognition). Tím, že je právo ovlivňováno praxí veřejných činitelů aplikujících právo, liší se pravidlo uznání od analytických pozitivistických teorií normativismu: pravidlo uznání představuje rovněž sociální normu. ${ }^{47}$ Je rovněž klíčové pro určení platnosti určitého pravidla jakožto právního pravidla, tedy pravidla náležejícího do určitého právního systému, 48 a z toho pohledu jde o základ celého právního systému. ${ }^{49}$ Samotné pravidlo uznání však neodvozuje platnost od dalšího pravidla možná v tom je jistá podobnost $\mathrm{s}$ Kelsenovou základní normou. Hlavní rozdíl však spočívá v tom, že postulovaná základní norma je hypotetický předpoklad neopírající se o praxi, pravidlo uznání je naproti tomu akceptováno ze strany veřejných činitelů jako vhodné a má tedy aspekt praxe veřejných činitelů. ${ }^{50}$ Hart na tomtéž místě přirovnává základní normu k standardnímu metru v Paříži, který byl v té době základem určování

41 HART, Pojem práva, s. 41 a násl.

42 POSTEMA, c. d., s. 269.

43 HART, Pojem práva, s. 100.

44 Tamtéž, s. 100-101.

45 Tamtéž, s. 103.

46 Tamtéž, s. 104.

47 ZIPURSKY, B. C. The Model of Social Fact. In: COLEMAN, J. (ed.). Hart's Postscript. Essays on the Postscript of the Concept of Law. Oxford: Oxford University Press, 2001, s. 219.

48 POTACS, M. Rechtstheorie. Wien: Facultas, 2015, s. 30. BIX, Jurisprudence: Theory and Context, s. 40.

49 POSTEMA, c. d., s. 310.

50 HART, Pojem práva, s. 115. POSTEMA, c. d., s. 317. 
délky (přičemž to, že měří právě jeden metr, nebylo možné dokázat jinak než tím, že na tom existuje shoda a tato délka je př́slušnými autoritami uznána). Toto zajímavé spojení normativity a fakticity u základu celého právního systému př̀dstavuje zásadní změnu oproti dosavadnímu pozitivistickému myšlení (Kelsen ve svých starších dílech např́ílad zásadně vylučuje svět faktů z oblasti normativního zkoumání).

Co je pravidlo uznání, popisuje Hart v páté kapitole Pojmu práva: „Bude specifikovat jistý rys či rysy, které budou u určitého navrhovaného pravidla považovány za přesvědčivé pozitivní znamení, že jde o pravidlo skupiny, jež bude podloženo jejím společenským tlakem. Takové pravidlo uznání může existovat $\mathrm{v}$ mnoha rozlišných jednoduchých i složitých formách. Může být pouhým autoritativním seznamem či textem pravidel, který se nachází v psaném dokumentu nebo je vytesán na některé veřejné památce, jak tomu bylo $\mathrm{v}$ raném právu mnoha společností. " ${ }^{\text {51 }}$ Po nástinu této jednoduché formy pravidla uznání se věnuje složitější verzi v současných právních řádech: „V rozvinutém právním systému jsou pravidla uznání pochopitelně mnohem složitější. Pravidla neidentifikují jen tím, že odkazují na určitý text či seznam: odkazuje i na některé charakteristiky, které jsou primárním pravidlům vlastní. Může jít o to, že je uzákonil specifický orgán nebo jsou v praxi ze zvyku už delší dobu uplatňována či mají vztah k soudním rozhodnutím. ... lze zavést i opatření, jež zajistí, aby tyto vlastnosti nebyly navzájem $\mathrm{v}$ rozporu - jsou uspořádány podle nadřazenosti, jako tř̌eba $\mathrm{v}$ případě podřízeného postavení zvyku nebo precedentu vůči zákonu, který představuje ,nadřazený pramen práva." ${ }^{52}$ Tato složitější podoba pravidla uznání tedy vytváří podle Harta v rozvinutých právních řádech systém pramenů práva a tím i strukturu celého právního řádu.

\section{ZÁKLADNÍ ROZDÍLY V OBOU KONCEPCÍCH SYSTEMATIKY PRÁVA}

Jak bylo nastíněno výše, významný britský sociolog Roger Cotterrell rozlišuje dva základní moderní př́stupy k právu: empirický a konceptualistický. Zastánci druhého jmenovaného vytvářejí pojmy a priori a jejich fungování v praxi pro ně není otázkou jejich existence. ${ }^{53}$ Konceptualistický prístup je typický např́ílad pro právní normativismus, snažící se metodologicky oprostit právní vědu od dalších společenských věd. Zastánci empirického př́stupu k právu naproti tomu vycházejí spíše ze sociologie; teorie pro ně představuje prímé zachycení empirické reality. ${ }^{54} \mathrm{Z}$ tohoto hlediska můžeme jak Harta, tak Luhmanna zařadit spiše mezi zastánce empirického př́stupu, byt', jak jsem poukázal výše, Hart nepřebírá pohled externího pozorovatele, nýbrž se snaží o popis práva z perspektivy účastníka systému. $\mathrm{V}$ jeho díle tak dochází $\mathrm{k}$ určitému sjednocení analytického pohledu na právo se sociologickým (v tezi o sociálním faktu) a psychologickým (rozdíl mezi donucením a zvykem poslušnosti).

\footnotetext{
51 HART, Pojem práva, s. 102.

2 Tamtéž, s. 103.

3 COTTERRELL, c. d., s. 81.

54 Tamtéž.
} 
Naproti tomu Luhmannova teorie je širší, nepopisuje pouze právní systém; právo vnímá jako jeden ze subsystémů společnosti, který se od nich liší, avšak zároveň není izolovaný. Na rozdíl od Hartovy teorie však Niklas Luhmann cíleně popisuje právo jako systém. Všímá si explicitně systémových vztahů, prvků, vazeb k okolí a konstruuje právo i jiné společenské subsystémy jako systémy autopoietické. V Hartově díle naproti tomu musíme systematiku práva podobně jako řadu dalších základních vlastností práva dovozovat, protože namísto vyčerpávající definice práva je v jeho díle podán souhrn podmínek, za kterých pravidla vytvářejí v moderních společnostech právní systém. K těmto podmínkám patří za prvé to, že právo musí kromě primárních pravidel obsahovat pravidla pro změnu, rozhodování a identifikaci. Za druhé, veřejní činitelé musejí jednat v souladu s pravidlem uznání a rozhodovat podle daných sekundárních pravidel. V neposlední řadě primární pravidla musejí být obecně akceptována, respektive internalizována, ze strany jejich adresátů. ${ }^{55}$

Kromě výše uvedené širší a užší perspektivy při pohledu na systém práva považuji za nejvýznamnější rozdíl v dílech obou autorů koncepci prvků systému práva. Současná právní teorie obvykle hovoří o právu jako o systému právních norem (resp., jak o tom pojednává Hart a další anglicky píšící autoři, jako systém právních pravidel - legal rules).

Při popisu Luhmannovy teorie právního systému je však třeba zdůraznit, že tento autor svým sociologickým pojetím chápe prvky tohoto systému odlišně. Prvky práva, tedy to, čím je právo tvořeno, souvisí především s jeho funkcí. Za tu Niklas Luhmann považuje stabilizaci a vytváření normativního očekávání. ${ }^{56}$ Pojem očekávání je jedním z mnoha specifických pojmů Luhmannovy teorie, a je vnímán šířeji než v běžném jazyce, nebot' zahrnuje „,̌asový aspekt nabývání významu komunikace v právu“. ${ }^{57}$ Atribut „normativní“ znamená, že se nejedná o empirický předpoklad kauzality. Př́kladem normativního očekávání je např́klad skutečnost, že pravidla o subjektivní odpovědnosti za škodu vytvářejí u subjektů normativní očekávání povinnosti nahradit škodu v př́padě zaviněného protiprávního jednání.

Základním prvkem práva tak podle tohoto pojetí nejsou abstraktní pravidla - právní normy - nýbrž široce pojímaná komunikace. ${ }^{58}$ Ta stojí v základu nejen práva, ale i všech dalších sociálních subsystémů. Do rámce komunikace zapadá i soudní rozhodování, Luhmannova teorie proto není příliš vzdálena Hartovu přístupu vymezujícímu právo jako sociální fakt. Eduard Bárány dokonce přirovnává důsledky Luhmannova pojetí práva k právnímu realismu s hlavní tezí, že právo je předpovědí rozhodovací činnosti soudů. Přitom však správně připomíná, že teorie autopoietického práva na straně jedné a právního realismu na straně druhé vychází ze zcela odlišných premis. ${ }^{59}$ Navíc, jak správně připomíná Martina Urbanová, komunikace ve smyslu Luhmannovy koncepce je veškerou sociální komunikací, která je formulována vzhledem k právu. Právo v tomto

55 Obdobně RIVAS, c. d., s. 417.

56 NOBLES, SCHIFF, Introduction, s. 14.

57 LUHMANN, Law as a Social System, s. 143.

58 Pro výměnu názorů mezi jednotlivci Luhmann používá pojem ,interakce“. „Komunikací“ naopak rozumí syntézu informací, porozumění těmto informacím a jejich vyjadřování. Viz KING, THORNHILL, c. d., s. 11 .

59 BÁRÁNY, E. Autopoietický sociálny subsystém právo? Sociológia, 2011, roč. 43, č. 2, s. 112. 
pojetí tak zahrnuje daleko více sociálních vztahů než v klasických koncepcích: např́íklad komunikaci o právu v každodenním životě. ${ }^{60}$

Se specifickým Luhmannovým pohledem na komunikaci jakožto základ práva, ale také dalších společenských subsystémů, souvisí i další rozdíl, kterým je postavení člověka jakožto aktéra práva. Na první pohled by se mohlo zdát, že rozdíly mezi oběma koncepcemi jsou značné - Niklas Luhmann nepovažuje aktéry za součást společenských subsystémů, umist'uje je mimo společenské systémy, avšak na druhou stranu jim přiznává vliv na utváření komunikace. Oproti tomu Hart pokládá zejména soudce za klíčové aktéry (například z hlediska pravidla uznání) a v obtížných př́ípadech aplikace práva jim přiznává diskreci při tvorbě nových pravidel. Ovšem z vazeb mezi společenskými systémy a lidmi ${ }^{61}$ plyne rovněž to, že přestože lidé mají vliv na podobu komunikace, zároveň to jsou však samotné sociální systémy, které kladou omezení libovolné komunikaci o právu. ${ }^{62}$

\section{SOUČASNÉ PRÁVO A JEHO VNITŘNÍ STRUKTURA}

Po druhé světové válce dochází minimálně ve státech kontinentálního právního systému ke kritice pozitivistického myšlení. Nově se rodící německá ústavnost byla založena nikoliv již výlučně na formální legalitě, nýbrž na hodnotových východiscích formulovaných napríklad Radbruchem. ${ }^{63}$ Tato hodnotová orientace je inspirována i některými předválečnými pracemi, např́íklad integrační teorií ústavy Rudolfa Smenda, ${ }^{64}$ podle níž z podstaty státu, kterou je integrace jednotlivců do společnosti, plyne i potřeba vnímat koherentní hodnotový základ celého právního ráádu. ${ }^{65}$

$\mathrm{K}$ argumentům hodnotami v právu záhy přistoupil argument právními principy, jakožto vůdčími právními idejemi obecnějšími než konkrétní právní pravidla (právní normy) ${ }^{66} \mathrm{~V}$ České republice je uznání právních principů jakožto pramenů práva spojeno do značné míry s rozhodovací činností „prvního“ Ústavního soudu. ${ }^{67}$ Ten v devadesátých letech opakovaně používal právní principy, ale také hodnoty v ústavním právu, a zahrnoval je tak do referenčního rámce přezkumu ústavnosti.

Pluralita prvků právního systému se odráží i ve struktuře práva. Martin Loughlin $\mathrm{v}$ této souvislosti používá pojem superlegalita, která se skládá $\mathrm{z}$ hodnot a principů zdůrazňovaných zejména $\mathrm{v}$ právní vědě doplňujících $\mathrm{v}$ britském právu rovinu psaného prá-

60 VEČĚ̌A, M. - URBANOVÁ, M. Sociologie práva. Plzeň: Aleš Čeněk, 2006, s. 59.

61 Lidé jsou v Luhmannově terminologii označováni jako psychické systémy.

62 NOBLES, SCHIFF, Observing Law through Systems Theory, s. 56-57.

63 RADBRUCH, G. Erneurung des Rechts. In: RADBRUCH, G. Rechtsphilosophie III. Heidelberg: C. F. Müller, 1990, s. 80-82. KRIELE, M. Grundprobleme der Rechtsphilosophie. Münster - Hamburg London, 2003, s. 6-7.

64 SMEND, R. Verfassung und Verfassungsrecht. In: SMEND, R. Staatsrechtliche Abhandlungen und andere Aufsätze. 4. Aufl. Berlin: Duncker und Humblot, 2010, s. 119-276.

65 HOLLÄNDER, P. Ústavněprávni argumentace. Ohlédnutí po deseti letech Ústavního soudu. Praha: Linde, 2003, s. 24. BOMHOFF, J. Balancing Constitutional Rights. The origins and meanings of post-war legal discourse. Cambridge: Cambridge University Press, 2013, s. 96.

66 ESSER, c. d., s. 95.

67 Za ,první“ Ústavní soud považuji první dekádu jeho činnosti, tj. od roku 1993 do roku 2003. Podrobněji k jeho činnosti viz HOLLÄNDER, Ústavněprávní argumentace, zejm. s. 62-85. 
va a soudní judikatury či precedentů, tvořící právní dimenzi legality. ${ }^{68}$ Legalita i tvrzená superlegalita práva ukazuje podle tohoto autora částečně odlišné zdroje autority práva. V prrípadě superlegality je to především právní věda, která argumentuje ve prospěch úlohy principů a hodnot v právu. Uvedená charakteristika právního systému se podle mého názoru netýká pouze států common law, podobně Josef Isensee používá pojmu meta-ústavy ve vztahu k ústavě v prakticky identickém významu, jaký má pojem superlegalita ve vztahu k legalitě v právním řádu obecně. ${ }^{69}$

Úvahy o existenci meta-ústavy jsou podle mého názoru významné i pro konstruování dalších ústavních doktrín, např́iklad klauzulí věčnosti či ústavní identity. ${ }^{70}$

V této souvislosti vnímám strukturu práva tvořenou v kontinentálním právu prvky plynoucími z psaných pramenů práva, ovšem také vnitřní strukturu práva opírající se o fundament práva $\mathrm{v}$ podobě nepsaných principů, hodnot či doktrín. Takto pojímaná struktura jednotného systému práva částečně odpovídá zaužívané německé koncepci vnitřního a vnějšího systému práva s tím rozdílem, že zdůrazňuji jednotnost systému práva. V německé právní teorii se za vnější systém práva označuje rozdělení právní látky (Einteilung des Rechtsstoffes), zejména na právní odvětví, jež se děje na základě technických hledisek a zajišt'uje přehlednost a zvládnutí matérie práva. ${ }^{71}$ Naproti tomu vnitřní systém práva představuje jeho hodnotovou orientaci. ${ }^{72}$

Hovoříme-li o vnitřní struktuře práva a jeho prvcích, je podle mého názoru potřeba zmínit význam ustálené judikatury a právní vědy. Soudní judikatura i odborná literatura totiž nejen dotvářejí právní normy a principy zakotvené v psaném právu, ${ }^{73}$ nýbrž v některých př́ípadech i konstituují samostatné doktríny, jež můžeme rovněž označit za prvky právního systému. To souvisí jednak obecně s kategorií uznání jakožto zdrojem normativity, ${ }^{74}$ jednak s pohledem na právo, které se uskutečňuje teprve chováním adresátů s důrazem na činnost veřejných činitelů majících pravomoc autoritativně rozhodovat konkrétní spory o právo, případně též právních vědců, kteří sice autoritativně nerozhodují, ale jejichž názory mohou být posléze aplikační praxí převzaty.

Jedním z důsledků uznání vnitřní struktury práva a nepsaných prvků právního systému je odmítnutí koncepce systematiky práva založené výlučně na systematice právních

68 Př́spěvek s názvem: Law, Autonomy and Authority přednesený na workshopu: Crisis, Modernity, Authority and the State konaném dne 21. záŕí 2018 na Právnické fakultě Univerzity Karlovy.

69 ISENSEE, c. d., s. 34. Meta-ústava v německém konstitucionalismu zahrnuje podle tohoto autora naprríklad spravedlnost a právní jistotu, dělbu moci, principy proporcionality, subsidiarity, solidarity.

70 Podobnou úvahu o pozadí ústavního práva rozvíjí M. Jestaedt rozlišující velkou ústavu (constitutio maior), obsahující její ideový, metafyzický a hodnotový základ, a malou ústavu (constitutio minor), vytvářející jevovou formu ústavní dogmatiky. K této teorii v české literatuře viz KYSELA, J. Ústava mezi právem a politikou. Úvod do ústavni teorie. Praha: Leges, 2014, s. 35 odkazující na publikaci JESTAEDT, c. d., zejm. s. 45 a násl. Právě členění na ústavní teorii a ústavní dogmatiku je podle M. Jestaedta důležité rozlišovat proto, aby nebyla ústava proměňována pouhou interpretací.

71 RÖHL, K. - RÖHL, H. Ch. Allgemeine Rechtslehre. 3. Aufl. Köln, München: Carl Heymanns Verlag, 2008, s. 439.

72 Tamtéž, s. 439-440.

73 Karel Eliáš připomíná známou myšlenku Ernsta Rabela přirovnávající zákon ke kostře, kterou obaluje judikatura jako svalstvo a kterou protkává panující doktrína jako nervová soustava. RABEL, E. Aufgabe und Notwendigkeit des Rechtsvergleichung. München: Max Hueber, 1925, s. 4 cit. dle ELIÁŠ, K. Př́íspěvek ke kultuře a precedentnímu působení civilních soudních rozhodnutí a právních vět. In: DVOŘÁK, J. MACKOVÁ, A. (eds.). Pocta Aleně Winterové k 80. narozeninám. Praha: Všehrd, 2018, s. 73.

74 Srov. výše kapitolu 2 tohoto článku. 
vět či předpisů. Pokud bychom totiž systém práva vnímali toliko jako systém právních předpisů, vyloučili bychom z rámce práva nepsané právní principy a hodnoty.

\section{ZÁVĚR: ČÍM PŘISPÍVAJÍ KONCEPCE SYSTEMATIKY PRÁVA H. L. A. HARTA A N. LUHMANNA K POJETÍ VNITŘNÍ STRUKTURY SOUČASNÉHO PRÁVA?}

Pokud bych se měl vrátit $\mathrm{k}$ fenoménům proměňujícím současné právo, o kterých jsem se zmínil v úvodu tohoto článku, přes různé diferenciační až fragmentační tendence je potřeba na současné právo hledět tak, že si klade nárok na systematický charakter. ${ }^{75}$ Zároveň se domnívám, že teorie H. L. A. Harta i N. Luhmanna mohou pomoci při popisu současného práva jako systému. Ani jedna z nich však podle mého názoru nepopisuje současné právo v jeho úplnosti. Oba autoři se však určitou částí svého díla dotýkají koncepce, kterou jsem označil za vnitřní strukturu práva. Hart, přestože se primárně soustředí na konkrétní právní pravidla, v závěru své kariéry připouští existenci nepsaných principů, pokud jsou kryty pravidlem uznání, ${ }^{76}$ Niklas Luhmann uznává roli doktríny či konstantní judikatury pro stabilizaci normativních očekávání adresátů práva. Zahrnutí principů, hodnot, eventuálně doktrín mezi prvky práva je sice produktem děl dalších autorů, ukazuje se však, že otázka systematiky práva souvisí především s popisem práva právní doktrínou, v čemž lze rovněž spatřovat souvislost $\mathrm{s}$ autopoietickým pojetím systému práva (sebereference v právu je totiž primárně produktem právní vědy).

Z významu principů, hodnot a doktrín pro právo lze dovodit, že právo nemůžeme vnímat jen jako systém konkrétních pravidel (právních norem). Takovýto pohled by z rámce práva vyloučil řadu prvků, které na rozhodování reálně působí. Znovu lze připomenout Hartem zastávaný význam diskrece pro řešení obtížných případů a také význam uznání pravidel ze strany veřejných činitelů (officials). Pro popis práva jako systému potřebujeme identifikovat jak principy a hodnoty vztahující se k př́íslušnému odvětví nebo institutu, tak i konkrétní doktríny a judikaturu, která se s jeho aplikací spojuje. Uznání principů a hodnot dále implikuje skutečnost, že na právo nelze pohlížet primárně jako na axiomatický, nýbrž jako na axiologický systém. ${ }^{77}$

75 Nárok na systémovost práva můžeme připodobnit k tezi o nároku práva na správnost (V originále Anspruch an Richtigkeit $\mathrm{v}$ anglicky psané literatuře claim to correctness. K těmto teoriím podrobněji v díle: ALEXY, R. Pojem a platnost' práva. Bratislava: Kalligram, 2009, s. 60 a násl.). Tento argument říká, že právní norma, individuální právní akt i celý právní systém nutně vznášejí nárok na to být správný. V samostatné rovině právní argumentace jde v př́ípadě správnosti o justifikovatelnost argumentačních závěrů (KLATT, M. Robert Alexy's Philosophy of Law as System. In: KLATT, M. (ed.). Institutionalized Reason. The Jurisprudence of Robert Alexy. Oxford: Oxford University Press, 2012, s. 15). V podobné rovině lze podle mého názoru tvrdit, že právo si klade nárok na to být systémem a v souvislosti s argumentací lze hovořit o nutnosti systematického pohledu na právo jako celek při řešení dílčího právního problému.

76 HART, Pojem práva, s. 257-258.

77 CANARIS, C.-W. Systemdenken und Systembegriff in der Jurisprudenz entwickelt am Beispiel des deutschen Privatrechts. In: NEUER, J. - GRIGOLEIT, H. C. (eds.). Claus-Wilhelm Canaris. Gesammelte Schriften. Bd. 1. Rechtstheorie. Berlin, Boston: Walter de Gruyter, 2012, s. 226. V české literatuře srov. nové články: HORÁK, F. - MADEJ, M. Možnosti a limity axiomatizace práva. Časopis pro právní vědu 
I přes rozšiřující se okruh prvků práva a užší vazby práva na další společenské subsystémy není možné podle mého názoru právo popisovat jako systém zcela otevřený, protože poté by se hranice mezi jednotou systému a jeho okolím vytratila. ${ }^{78}$ Zároveň je ale zřejmé, že právo se ani neuzavírá do vlastní logiky, nýbrž reflektuje své okolí a komunikuje s ním. ${ }^{79}$ Při tomto popisu autonomie práva, které podle mého názoru musíme dát atribut relativní, můžeme využít některé závěry systémové teorie práva.

Konkrétně se relativní autonomie práva projevuje především v tom, že je to právo samo, které konceptualizuje a následně používá doktríny a pojmy vyskytující se například v ekonomii, filozofii nebo politice. Řada otázek, které řeší ekonomie či politika (např. „dluhová brzda“ veřejných rozpočtů, bankovní poplatky pro spotřebitele, nerovnost $\mathrm{v}$ odměňování mužů a žen na trhu práce), je pojímána v právu jako právní problém navazující na související právní hodnoty, principy a doktríny. Komunikace práva s okolím tedy probíhá na základě institucionalizovaných procesů v právu, případně postupů rozvíjených právní vědou (např́íklad metodologie interpretace práva).

JUDr. Pavel Ondřejek, Ph.D.

Právnická fakulta Univerzity Karlovy

ondrejek@prf.cuni.cz

ORCID: 0000-0001-6764-8993

a praxi, 2018, roč. 26, č. 1, s. 149-168; MADEJ, M. - HORÁK, F. Axiomy v právní argumentaci: dvousečná zbraň v rukou orgánů aplikujících právo. Jurisprudence, 2018, č. 5, s. 29-42.

78 NOBLES, SCHIFF, Observing Law through Systems Theory, s. 6.

79 Je sice možné postulovat logicky uzavřený systém, ovšem takováto myšlenková konstrukce naprosto izolující právo od prostředí, v němž je realizováno a aplikováno, je velmi abstraktní a obtížně se vypořádává s celou řadou jevů reálného působení práva. 